\title{
Discovering Gaps in Internationalization Competences of SMEs-a Comparative Case Study of Austrian SMEs
}

\author{
Johanna Anzengruber \\ Correspondence: Johanna Anzengruber, School of International Business \& Entrepreneurship, Steinbeis University \\ Berlin, Germany
}

Received: January 26, 2015 Accepted: February 11, 2015 Online Published: February 27, 2015

doi:10.11114/bms.v1i1.643

URL: http://dx.doi.org/10.11114/bms.v1i1.643

\begin{abstract}
This article adds to the debate on internationalization competences of SMEs. After an examination of the most influential papers, we systematically discuss the role of individual and organizational competence gaps before and during the internationalization phase. In more detail, we raise the question what kinds of competences gaps hinder SMEs to go international and what competence gaps arise during the internationalization. This is done using a comparative case study design with competence gap data from twenty-four SMEs in China and Austria. Our research reveals severe differences in competence gaps among those SMEs who have internationalized and those who will internationalize theirs businesses. Indeed, we found out that while internationalized SMEs perceive organizational competence gaps as higher as individual ones - exactly the opposite is found at the SMEs working exclusively in their home markets. We conclude by proposing a systematic, continuous, and task-oriented allocation of the competence development efforts.
\end{abstract}

Keywords: internationalization, Austria, SME, R\&D, innovation; competence

\section{Introduction}

Having a holistic international strategy, an entrepreneurial vision, and great networking capabilities are often argued to be the key to a successful SME internationalization (Achtenhagen, 2011). Therefore, a large amount of scholars have focused their attention and efforts on exploring these aspects to guide SMEs in their "geographical expansion of activities over a nation's boarders" (Ruzzier et al. 2006, p. 477). In the course of time, various approaches emerged that served the purpose of explaining the notion of internationalization and of facilitating SMEs in their internationalization process - so challenges in terms of access, finance, know-how and manpower could more easily be overcome (Forsman et al., 2002).

However, according to Achtenhagen's 2011 study, a large amount of SMEs could internationalize but lack the willingness or the competences to do so. One reason for that seems to be the fear to change entrepreneurial practices. Another reason appears to be the little international experience of SMEs management teams.

Surprisingly, we still found little empirical evidence about how in general, competences influence and determine the internationalization of SMEs and in particular about how lacking competences being the reason for hindering the internationalization process. Attempts of the scientific community to shed light into the dark resulted in advising ramp-up activities of primarily networking and cooperation skills. Research on how internal competences can become drivers of internationalization (G. Di Stefano et al., 2012; Lin 2010) has led to more questions arising. Thus, what is known is that the internationalization of SMEs does not primarily come from a single source but rather than from the combination of the entrepreneur, the company as well as the environment. In this respect, competences could to work as "crucial crossroads to assimilate and combine external knowledge within firm boundaries" (G. Di Stefano et al., 2012) to ease the internationalization.

To discover further insights into the role of competences for the SME internationalization, we attempt to raise the following questions in this paper: How do competences affect the internationalization process? What competences SMEs perceive to lack in the pre-internationalization phase or during the internationalization process per se? What competences do they need to develop themselves further?

Overall, we propose a more facetted approach to competences, its nature and understanding by opening up the room for the discussion on the effects of individual and organizational competences on different aspects of the 
internationalization process. We argue for a more nuanced differentiation and understanding as "in the long run, sustainability of competitiveness of a firm will be associated with the management of learning processes that will reinvigorate and enhance organizational competences and will fine-tune and reposition competitive strategies" (Fleury \& Fleury 2005, p.1644). To this aim we perform a comparative qualitative case study which suits the purpose of dismantling SMEs competence gaps in more detail than quantitative approaches could do.

Understanding in which phase individual or organizational competence gaps are more severe could help companies and policy makers to allocate their resources more efficiently and effectively. Therefore, a vast amount of "unproductive" investments and discussions currently undertaken could be then redirected to more promising activities that generate valuable outputs. We do so, as we believe that competences as drivers for internationalization are currently underestimated by managers and scholars.

The remainder of the article is structured as follows. In section two the existing literature on internationalization and competence are critically discussed. Gaps are highlighted. As a consequence, we develop our research question. Section 3 explains our research design, methodology, and sample of the study. In section 4, we will present the results of the qualitative analysis. The article continues with the discussion of the findings and implications in section 5. Finally, it concludes by explaining the limitations as well as setting directions for further research.

\section{Internationalization Competences}

Section 2.1 outlines the role of competences for internationalization in an SME setting. It draws on diverse literature concerning competences of individuals, while Section 2.2 provides insights into the domain of organizational competence as well as explores the gaps, and presents the research question.

\subsection{Merging Internationalization \& Competence}

Integrating the understanding of competences and their functions into the internationalization approach is fairly new, even though the internationalization serves per se the purpose of shifting resources and competences from one location to another. The internationalization is furthermore known as a collective process by the actors and theirs competences as well as the firm's competences in order to achieve a strategic process. Competences provide in this respect - in tangible or intangible form - "an integrative vision on internationalization" (Lin 2010, p. 13) as well as opportunities for additional, new value creation for the market (Hébert, 2002). In addition, the competences serve as the bases for internationalization approaches like the stage gate, the network or the international entrepreneurship approach. Overall, Lin (2010) calls competences "a framework to compensate the insufficiencies of the stage approach by explaining how and why SMEs can pass certain steps in their internationalization" (Lin 2010, p. 13).

Looking back in time, the pioneer in resources and competences approach was Penrose in 1959. Based on his thoughts, four different approaches emerged: the resource approach (Wernerfeld, 1984; Barney, 1986), the evolutionary theory by Nelson and Winter (1982), the core competence approach by Hamel and Prahalad (1990) and the youngest one, the theory of dynamic capabilities by (Teece, Pisano \& Shuen, 1997). All the approaches are based implicitly in the notion of competences (Laghzaoui, 2009). While Bigler and Nyffler (2006) differentiate between strategic, operational and technical competences, Pantin (2005) classifies competences whether they are used for entering a foreign market or needed for the carrying out of the action itself. Wilkens (2004) distinguishes competences on four levels - on the individual, group, organizational and network level. These competences used for the internationalization of a business can be of financial and technological or entrepreneurial nature (McDougall \& Oviatt, 2000; Dhanaraja \& Beamish, 2003).

Picturing competence from a theory perspective, the competence-based view of the firms argues towards the uniqueness of the single firm and stresses corporate strength. The main mission of this theory is to develop innovative strategic architectures through estimating the future (Hamel and Prahalad, 1994) and creatively eliminate current environments. Moreover, the competence-based thinking facilitates the identification and generation of new market opportunities (Freiling, 2004). But it also fosters the linkage of the collective staff's competences to a firm's past, present and future activities (DeFilippi \& Arthur 1996; Heilmann, 2011).

Despite the considerable advances in the debate, the main stream of competence literature focuses either on capabilities and core competences of firms grounded in the resource or knowledge based view (known to and practiced by Strategy Departments in firms) or on people competences based on a psychological and sociological perspective (known to Human Resources Departments in firms) (Wilkens, 2004). A combination of two levels as called for by Jacobides and Winters (2012) and G. Di Stefano et al. (2012) is rarely found. In this paper, we attempt to combine the individual and the organizational level respectively. In the center of this study, we find the entrepreneur, the company as well as the environment. In the following, we will refer to the entrepreneur, as individual level and to the company as well as the environment, as organizational level. In addition, we have to recognize a certain amount of diversity in the need as 
different kinds of competences become important at different steps of the internationalization process of an SME. In this respect, it should become evident that the "Internationalization competence of SMEs entails not only knowledge about how to enter a foreign market, it also comprises a range of other competences" (Achtenhagen 2011, p. 38) as how to grow in a foreign market as well as intercultural ones. However, we have to stay aware, that even if competences can enhance the internationalization performance (Rahmandad, 2012) - such findings can only be rated as pieces to the puzzle helping to explain how and why internationalization processes especially for small firms work (Pantin, 2006).

\subsection{Internationalization Competence on Individual Level}

Recent research (Hutchinson et al., 2006) argued for the entrepreneur or SME manager to play a key role in the internationalization process. Johanson and Vahle (1990), for instance, declare that the experimental knowledge of an SME manager is a determinate of success. But not only the entrepreneur's know-how but also his decision making capabilities in marketing and financial aspects and foremost his action-orientation are highly discussed and valued among scholars. For instance, Hutchinson et al. (2006) argue for only letting managers with international experience lead the internationalization process of an SME - as this kind of expertise appears business critical. Also assistance from a consulting agency and hiring a new experienced talent are considered as ways. According to Reuber and Fischer (1997) the more international experience a management team has, the faster an SME goes international.

Further, scholars found that manager's value system, the attitude as well as the profound understanding of the market heavily determine the success of an internationalization process (Leonidou \& Katsikeas, 1996). In terms of personal international orientation, relevant aspects are international experience and orientation, cross-cultural understanding and the ability to recognize international business opportunities (Chandra et al., 2009). "A manager's world rather than a country perspective, the ability to scout for business opportunities, the communication and management competence will make up a large stake on the firm's international market success" (Knight \& Kim 2009, p. 264; Achtenhagen 2011, p. 22). In addition, networking competences are said to facilitate the information gathering as well as the interaction with partners as developing and relying on a network in a foreign country can improve the competitiveness for SMEs. For example, by taking support services and suppliers into account, the host-country specific factors can be exploited on the road to develop new distinctive competences. Moreover, competences play a vital role before, at and after decision making by the entrepreneur. While they first influence the intention and choices, then they influence the length, and then the justification and the commitment, creating a certain rhythm and intensity in the internationalization process (Laghzaoui, 2009).

What all of these attributes and examples have in common is the notion of creating superior value. This is exactly what competency is all about - developing sets of knowledge, abilities, and attitudes that lead to superior performance. "Competency is an underlying characteristic of an individual that is causally related to criterion referenced effective and/or superior performance in a job or a situation" Boyatzis (1982, p. 21). It is more than processes, routines knowledge and qualification - it is an individual's "own organizational disposition" (Grote et al. 2006; Heyse \& Erpenbeck, 2004) which take place beyond the scope of routines and allow radical innovations to rise from the idea and the successful implementation. So, the amount and the strengths of competences heavily influence the choices by managers on strategic as well as operational level, for instance the decision to go international or the choice of international's structure or partnering and learning (Wolff and Pett, 2000).

\subsection{Internationalization Competence on Organizational Level}

Besides individual competences, competences play a central role on the firm's and environment's level in a SMEs internationalization process - from the development strategies, to entry modes and market selection (Hébert, 2002; Dhanaraja \& Beamish, 2003; Rasheed, 2005).

However, not the whole organization or the whole environment is engaged in the internationalization process at the same time and to the same extend. The process of internationalization is a result of a combination of activation of competences inside and outside for the firm. Depending on the level of availability and proficiency, "the ability of an organization to sustain coordinated deployments of resources in ways that help the organization to achieve its goals" (Sanchez \& Heene 2004, p. 7), varies.

Following Knight and Kim (2009) several organizational competence based activities are relevant for internationalizing, for instance: international innovativeness, international market orientation with customer, competitor and interfunctional perspectives, as well as institutional knowledge. Depending on the size of an SME, international operations - focused on financial, technological and productive competences (Suarez-Ortega \& Alamo-Vera, 2005) -, the internationalization strategy (choice of ownership, location, and partners) and the entry mode differ and matter differently (Lin, 2012). Knight and $\operatorname{Kim}(2009$, p. 265) characterize a couple of elements of international innovativeness, for instance, "leading technological edge, embedded invented technology in products and market it first compared to competition, recognized in international markets, high technological expertise among the members". Focusing on the 
tasks and activities that different departments in an SME have to carry out, we find all activities from purchasing, contract negotiations exporting, development, testing, production, processing technology, distribution, sales and marketing, quality, overseas management, and human resources in which competence is required but often lacking (Porter, 1998; Achtenhagen, 2011; Katwalo, 2006). In this respect, Wilkens et al. (2004) argue that generating "organizational internal processes of action and interactions are decisive for the generation of core competencies" (Wilkens et al. 2004, p. 11) and core competences is what an international part of an SME needs to gain to be successful in the host-country.

However, only focusing on the companies inside the company would provide a fragmented picture. Therefore, we turn our focus towards the environment and its competences. In this respect, Fourcade (2002) for instance, argues for leveraging competences that enable organizations to communicate and position themselves and develop theirs international activities like market, technology, suppliers, customers, and competitors. In his perspective, in order to apply new knowledge about markets, technology, suppliers, customer, and competitors, firms need to learn how to use its resources and competences efficiently. The actors in the environment facilitate the internationalization of an SME through providing opportunities to learn and gain skills.

In summary, through combining these three perspectives, we are able to enhance the capacity to develop and sell new products, services, processes, and business models in other markets, outside our home market. In the following, the summary of internationalization competences is listed.

Table 1. Internationalization competences (based on Achtenhagen 2011; Katwalo, 2006; Knight \& Kim, 2009; Porter, 1998; Wilkens et al. 2004)

\begin{tabular}{l}
\hline Internationalization competences \\
\hline Individual (SME Manager's) perspective: \\
International experience (Personal competence) \\
Cross cultural competence in identifying business opportunities (Socio-communicative \\
competence) \\
Cross cultural communication competence (Socio-communicative competence) \\
International orientation (Personal competence) \\
Organizational perspective: \\
International innovativeness \\
International marketing skills \\
International market orientation (Competitor, Interfunctional, institutional orientation) \\
Activity Competences \\
Inbound logistics \\
Operations \\
Outbound logistics \\
Marketing and Sales \\
Service \\
Human Resource Management \\
Technology Development \\
Procurement \\
Overseas Management \\
Financial Management \\
\hline
\end{tabular}

Nevertheless, after scanning the most influential literature, only partly-connected pieces of the puzzle emerged through the review. In essence for us, competence covers various attributes on various levels in organisations. By analysing the current frameworks, we had to realize that the existing research results provide unsatisfying answers to our research question: "What kinds of competences gaps hinder SME to go international and what competence gaps arise in the internationalization process?" We clearly found a lack of research results in this field. In this study, we, therefore, 
attempt to contribute to the closure of this gap by exploring where SMEs perceive to have the greatest competence gaps that hinder them to internationalize. We use a case study approach and perform research on the micro level. We focus the first of a series of empirical studies in this field on investigating the individual and organizational competence gaps of SMEs in the internationalization process among different sectors and tasks.

\section{Method}

In order to explore the competences and the competence gaps of the SMEs in the internationalization process, we used a comparative case-study design (Yin, 1994). Comparative case-studies are empirical inquiries that "investigate a contemporary phenomenon within its real-life context when the boundaries between phenomenon and context are not clearly evident and in which multiple sources of evidence are used" (Yin 1989, p. 23). Case studies in essence are "more a research philosophy than a research method" (Hartley 2004, p. 323) with the goal to generate hypotheses and to develop theory (Patton \& Appelbaum 2003). With this method, science and practice can be merged. Its use allows researchers to understanding complex situations - without having to give up a holistic perspective.

Based on the list of SMEs by the Austrian Chamber of Commerce, we clustered the companies according to the SME status, their location, year of foundation, the manager's years of international experience, and the SMEs international presence or non-presence. Via short telephone interviews, we checked the SMEs willingness and the suitability for our study. In total, we conducted 13 semi-structured interviews with SME managers in charge of internationalization and 11 with SME managers staying national - but considering going international in the next 2 years. The SMEs come from eight sectors with the emphasis ramping up production facilities, service centers or representation offices. The sample was selected because of the contrasting situations (e.g. locations, age, and managers' international experience).

The interviews focused on what kind of internationalization strategy and targets the SMEs follow as well as which competences they have and lack, and which competences hinders them to go international and why. We divide competence into two aspects: individual and organizational competence attributes. One the one hand, we used an open question format - on the other, we used a closed format to be able to rate the competences. A common rating for the evaluation of was defined and condensed into overall proficiency levels - Beginner, Basic, Advanced and Expert - as introduced in Anzengruber and Bernard (2009). A four-point scale was used for rating the proficiency level for each competence. The names and numbers of the proficiency levels are used to guarantee transparency among the proficiency levels. Competencies are graded in levels using a numerical scale and verbal schema. The classification scale is based on an ordinal scale. Because competences are always positive, a negative scale was not included. If a certain level is reached, this implies that the person also meets the criteria for the levels below.

To determine the gap, we ask not only for the competence level today but also for the competence level, the SME should have ideally to be successful in their international business. By comparing the proficiency levels, we receive a perceived gap. We rate the gap as a low gap, if the difference is only one step (for example advanced to expert), as a medium gap, if the difference is two proficiency levels (for example basic to expert), and as a high gap, if the difference is three proficiency levels; for example beginner to expert). We also ask for the competence gap impact on the business and the internationalization process per se. For the ratings we used a 5 -point Likert scale from (none $=0$; low $=1$; medium $=2$; high $=3$; very high=4).

We recorded the interviews which took place in 2011 and wrote notes which helped us to extract the essentials and further develop a systematic understanding. Besides our interviews and the data we were granted access to, we talked informally with various employees and asked questions about the competence strengths and potentials for improvement. The study provides rich findings, but is based on a relatively small sample only permitting only questionable generalization. To construct validity (Yin, 1989), we use a number of different sources of data to facilitate data triangulation. We use a mix of primary and secondary data. 
Table 2. Illustration of case study sample - distinguishing international from national SMEs

\begin{tabular}{|c|c|c|c|c|c|c|c|c|c|c|}
\hline$\#$ & $\begin{array}{l}\text { \# of } \\
\text { staff }\end{array}$ & Sector & $\begin{array}{l}\text { Production/Service } \\
\text { / Representation }\end{array}$ & Location & $\begin{array}{l}\text { Host-country } \\
\text { location }\end{array}$ & $\begin{array}{l}\text { Year of } \\
\text { foundation }\end{array}$ & $\begin{array}{l}\text { SME Manager's } \\
\text { role }\end{array}$ & $\begin{array}{l}\text { Nation } \\
\text { ality }\end{array}$ & $\begin{array}{l}\text { Manager's } \\
\text { age 20-35 } \\
\text { (1); 35-50 } \\
\text { (2); > 50 (3) }\end{array}$ & $\begin{array}{l}\text { Manager's } \\
\text { inter- } \\
\text { national } \\
\text { experience } \\
\text { in years }\end{array}$ \\
\hline 1 & 132 & $\begin{array}{l}\text { non-steal } \\
\text { industry }\end{array}$ & production & AUT & $\begin{array}{l}\text { Guangdong } \\
\text { province }\end{array}$ & 1995 & $\begin{array}{l}\text { Managing } \\
\text { Director }\end{array}$ & AUT & 2 & 9 \\
\hline 2 & 24 & healthcare & production & AUT & $\begin{array}{l}\text { Jiangsu } \\
\text { Province }\end{array}$ & 2002 & $\begin{array}{l}\text { General } \\
\text { Manager }\end{array}$ & AUT & 2 & 4 \\
\hline 3 & 12 & $\begin{array}{l}\text { light } \\
\text { industry }\end{array}$ & production & AUT & Shanghai & 2002 & $\begin{array}{l}\text { Managing } \\
\text { Director }\end{array}$ & AUT & 2 & 4 \\
\hline 4 & 121 & $\begin{array}{l}\text { non-steal } \\
\text { industry }\end{array}$ & production & AUT & Suzhou & 1997 & $\begin{array}{l}\text { Managing } \\
\text { Director }\end{array}$ & $\mathrm{CHN}$ & 2 & 4 \\
\hline 5 & 10 & $\begin{array}{l}\text { light } \\
\text { industry }\end{array}$ & production & AUT & Suzhou & 2003 & $\begin{array}{l}\text { General } \\
\text { Manager }\end{array}$ & AUT & 2 & 6 \\
\hline 6 & 7 & $\begin{array}{l}\text { infrastructur } \\
\mathrm{e}\end{array}$ & representation & AUT & $\begin{array}{l}\text { Guangdong } \\
\text { province }\end{array}$ & 2001 & $\begin{array}{l}\text { General } \\
\text { Manager }\end{array}$ & $\mathrm{CHN}$ & 2 & 1 \\
\hline 7 & 1 & $\begin{array}{l}\text { infrastructur } \\
\mathrm{e}\end{array}$ & representation & AUT & $\mathrm{HK}$ & 2001 & Representative & $\mathrm{CHN}$ & 2 & 2 \\
\hline 8 & 3 & insurance & representation & AUT & $\mathrm{HK}$ & 2001 & Representative & AUT & 2 & 3 \\
\hline 9 & 6 & education & representation & AUT & $\mathrm{HK}$ & 2003 & Entrepreneur & AUT & 2 & 4 \\
\hline 10 & 5 & $\begin{array}{l}\text { light } \\
\text { industry }\end{array}$ & representation & AUT & Shanghai & 2002 & Representative & AUT & 1 & 1 \\
\hline 11 & 34 & healthcare & services & AUT & HK & 2004 & $\begin{array}{l}\text { Managing } \\
\text { Director }\end{array}$ & AUT & 1 & 3 \\
\hline 12 & 89 & $\begin{array}{l}\text { Telecommu } \\
\text { nication }\end{array}$ & services & AUT & Shanghai & 1985 & $\begin{array}{l}\text { Managing } \\
\text { Director }\end{array}$ & AUT & 1 & 8 \\
\hline 13 & 92 & tourism & services & AUT & $\begin{array}{l}\text { Shanghai, } \\
\text { HK }\end{array}$ & 2005 & Representative & AUT & 1 & 7 \\
\hline 14 & 66 & healthcare & production & AUT & N.A. & 2006 & $\begin{array}{l}\text { Managing } \\
\text { Director }\end{array}$ & AUT & 2 & 2 \\
\hline 15 & 132 & $\begin{array}{l}\text { non-steal } \\
\text { industry }\end{array}$ & production & AUT & N.A. & 1988 & $\begin{array}{l}\text { Managing } \\
\text { Director }\end{array}$ & AUT & 2 & 1 \\
\hline 16 & 179 & healthcare & production & AUT & N.A. & 2002 & $\begin{array}{l}\text { Managing } \\
\text { Director }\end{array}$ & AUT & 2 & 1 \\
\hline 17 & 114 & $\begin{array}{l}\text { infrastructur } \\
\text { e }\end{array}$ & production & AUT & N.A. & 1999 & $\begin{array}{l}\text { General } \\
\text { Manager }\end{array}$ & $\mathrm{H}$ & 2 & 3 \\
\hline 18 & 78 & $\begin{array}{l}\text { Telecommu } \\
\text { nication }\end{array}$ & services & AUT & N.A. & 1997 & $\begin{array}{l}\text { Managing } \\
\text { Director }\end{array}$ & AUT & 2 & 1 \\
\hline 19 & 93 & $\begin{array}{l}\text { Telecommu } \\
\text { nication }\end{array}$ & services & AUT & N.A. & 2001 & $\begin{array}{l}\text { Managing } \\
\text { Director }\end{array}$ & AUT & 2 & 0 \\
\hline 20 & 78 & education & services & AUT & N.A. & 2003 & $\begin{array}{l}\text { General } \\
\text { Manager }\end{array}$ & GER & 1 & 0 \\
\hline 21 & 212 & insurance & services & AUT & N.A. & 1997 & $\begin{array}{l}\text { General } \\
\text { Manager }\end{array}$ & $\mathrm{CZ}$ & 2 & 4 \\
\hline 22 & 45 & education & services & AUT & N.A. & 2008 & Entrepreneur & AUT & 2 & 1 \\
\hline 23 & 9 & tourism & services & AUT & N.A. & 2006 & Entrepreneur & AUT & 1 & 0 \\
\hline 24 & 36 & tourism & services & AUT & N.A. & 2000 & Entrepreneur & AUT & 2 & 0 \\
\hline
\end{tabular}

\section{Results}

In summary, our accumulated research shows the following: While internationalized SMEs (referred in the latter as group one) perceive organizational competence gaps as higher as individual ones-exactly the opposite is found at the SMEs working exclusively in their home market (referred in the latter as group two). This is a surprising result as the current literature does not make a distinction here. In the next sub-sessions, we will discuss the different outcomes and what they mean in the context. Condensed results are depicted in Table 3: 
Table 3. Competence gap results of our research sample

\begin{tabular}{|c|c|c|c|c|c|c|c|c|c|c|c|c|}
\hline & \multicolumn{6}{|c|}{ Internationalized SME (gaps rated by international SME managers) } & \multicolumn{6}{|c|}{ SMEs (not international; SMEs perceive theirs gaps for going international) } \\
\hline & $\begin{array}{l}\text { repres } \\
\text { Competence } \\
\text { gap }\end{array}$ & $\begin{array}{l}\text { entation } \\
\text { competence } \\
\text { impact on } \\
\text { business }\end{array}$ & $\begin{array}{l}\text { pro } \\
\text { Competence } \\
\text { gap }\end{array}$ & $\begin{array}{l}\text { uction } \\
\text { competence } \\
\text { impact on } \\
\text { business }\end{array}$ & $\begin{array}{l}\text { Competence } \\
\text { gap }\end{array}$ & $\begin{array}{l}\text { vices } \\
\text { competence } \\
\text { impact on } \\
\text { business }\end{array}$ & $\begin{array}{l}\text { repre } \\
\text { Competence } \\
\text { gap }\end{array}$ & $\begin{array}{l}\text { entation } \\
\text { competence } \\
\text { impact on } \\
\text { business }\end{array}$ & $\begin{array}{l}\text { Competence } \\
\text { gap }\end{array}$ & $\begin{array}{l}\text { luction } \\
\text { competence } \\
\text { impact on } \\
\text { business }\end{array}$ & $\begin{array}{l}\text { Competence } \\
\text { gap }\end{array}$ & $\begin{array}{l}\text { vices } \\
\text { competence } \\
\text { impact on } \\
\text { business }\end{array}$ \\
\hline \multicolumn{13}{|c|}{ Individual (SMEManager's) perspective: } \\
\hline $\begin{array}{l}\text { International experience (Personal } \\
\text { competence) }\end{array}$ & medium & high & low & low & low & high & NA & $N A$ & high & low & high & medium \\
\hline $\begin{array}{l}\text { Cross cultural competence in } \\
\text { identifying business opportunities } \\
\text { (Socio-communicative competence) }\end{array}$ & low & veryhigh & low & medium & low & high & NA & $N A$ & medium & high & high & high \\
\hline $\begin{array}{l}\text { Cross cultural communication } \\
\text { competence (Socio-communicative } \\
\text { competence) }\end{array}$ & medium & very high & low & medium & medium & high & NA & $N A$ & high & low & medium & high \\
\hline $\begin{array}{l}\text { International orientation (Personal } \\
\text { competence) }\end{array}$ & medium & high & low & medium & low & high & NA & $N A$ & medium & medium & high & high \\
\hline \multicolumn{13}{|c|}{ Organizational perspective: } \\
\hline International innovativeness & medium & medium & low & veryhigh & high & medium & NA & NA & high & medium & medium & medium \\
\hline International marketing skills & low & high & medium & high & medium & medium & NA & NA & high & medium & high & high \\
\hline International market orientation & low & high & low & high & low & medium & $N A$ & NA & high & high & high & high \\
\hline Activity Competences & & & & & & & $N A$ & NA & & & & \\
\hline Inbound logistics & NA & NA & low & high & NA & NA & NA & NA & low & high & low & low \\
\hline Operations & NA & NA & high & veryhigh & medium & high & NA & NA & low & medium & low & low \\
\hline Outbound logistics & NA & NA & medium & high & NA & NA & NA & NA & low & high & low & low \\
\hline Marketing and Sales & low & high & medium & medium & medium & medium & $N A$ & $N A$ & medium & medium & medium & high \\
\hline Service & low & high & medium & medium & medium & medium & NA & $N A$ & NA & medium & medium & low \\
\hline Human Resource Management & high & medium & medium & high & medium & medium & NA & NA & low & low & low & low \\
\hline Technology Development & NA & NA & high & high & NA & NA & NA & $N A$ & high & medium & NA & NA \\
\hline Procurement & NA & $N A$ & high & high & low & low & $N A$ & $N A$ & low & high & low & low \\
\hline Overseas Management & low & low & high & high & high & high & NA & NA & low & medium & low & medium \\
\hline Financial Management & low & low & medium & low & low & medium & NA & NA & medium & low & medium & medium \\
\hline
\end{tabular}

\subsection{Individual Competences}

In detail, the results of the comparative case study show that cross cultural competence in identifying business opportunities are rated low in internationalized SMEs and medium to high in the national SMEs. Group one rates the gap degree of the internationalization orientation competence in the internationalization process low to medium while group two rates it medium to high. One Hong Kong SME manager commented his low gap score: "I have worked more than 12 years abroad and more than 15 years in the international context. During the last 8 years that I have been with the company, we have learned to handle intercultural differences as a team and respond to intercultural barriers with openness (most of the time). We have an international communication set up and our culture is not Austrian - nor Hongkongese it is both. Our Headquarters recognizes our demands and responds to it - and the opposite around. We have built up core competences here. So, I am quite impressed".

On the contrary, according to your case study individual competence gaps are perceived to be the number one reason for not going international in group two. One reason for that appears to be that in the mind of many entrepreneurs missing factors like international experience, language skills, and business contacts hinder severely the way forward. "Before I go international with my team, I need to send them all to intercultural trainings and language courses." However, organizational competence gaps are not perceived as strong by group two. These ratings go in line with the statements we received during the interviews: "We are among the quality leaders of our country and we have excellent experts on norms - so we don't expect that institutional barriers will be hard to overcome", so a SME manager in the infrastructure business. Another national SME manager: "The reason for us that we are not yet present in international markets is that we are a team with hardly any international work experience. We are the best providing services to our home community. Our business reflects our values. We are uncertain, if our values would be met abroad - but if, ramping up organizational competences will not be a main hurdle." A third reflected: "We are risk adverse - always have been. Our business is a traditional family business and our customers are network based. So we are good at networking, but finding people that can represent us outside the network will be challenge. I expect, finding the right candidate for that job, is the hardest part."

\subsection{Organizational Competences}

The results change dramatically, when we turn from individual competence gap ratings to the organizational ones. Lacking organizational competences are perceived as more severe when the internationalization is already in process. 
For example, operations, service, human resource management, technology management and overseas management show medium to high gaps in group one and mainly low to medium gaps in group two. Interviewees commented the differences with: "Our biggest challenge in our production facility is to get our incremental technology development and our operations up to speed. We are currently under a lot of pressure by our competitors that will launch a new product line next months. We have to respond to that." Another one states: "As a representative organization of an Austrian SME, our greatest competence gaps lie in the innovativeness - as we are depended on the products of our Headquarters. We are currently trying to get authority to develop and see products for the local market. When we move to this stage, we believe that larger organizational competence gaps will appear."

\subsection{Competence Impact on Business}

The factors, cross cultural competence in identifying business opportunities, cross cultural communications, international innovativeness, and operations appear to have a very high impact on the business. In terms of organizational competences, we found a combination of high gaps and high impact of competences in international marketing skills, international market orientation and technology development in both groups. For SMEs with production facilities, individual competences have a low impact on the business, while SMEs engaged in services and representation state the opposite. Group one shows a high impact and gaps in the fields of operations and outbound logistics, and procurement. Group two perceives that marketing and sales as well as service must be systematically developed. "We will focus our ramp up on streamlining our operations. We have our set up now for several years and we need to become more efficient. This is a great challenge" - one of the interviewee's commented.

Overall, the impact of organizational competences on the business varies largely: having a great impact in production, medium impact in services, and low impact in representation tasks of SMEs. The implications from these results are obvious: Competence development will vary heavily depending on the tasks of the SME. This has to be taken into account when setting up international operations. Our illustration on matching competence impact on business and competence gaps shows the following:

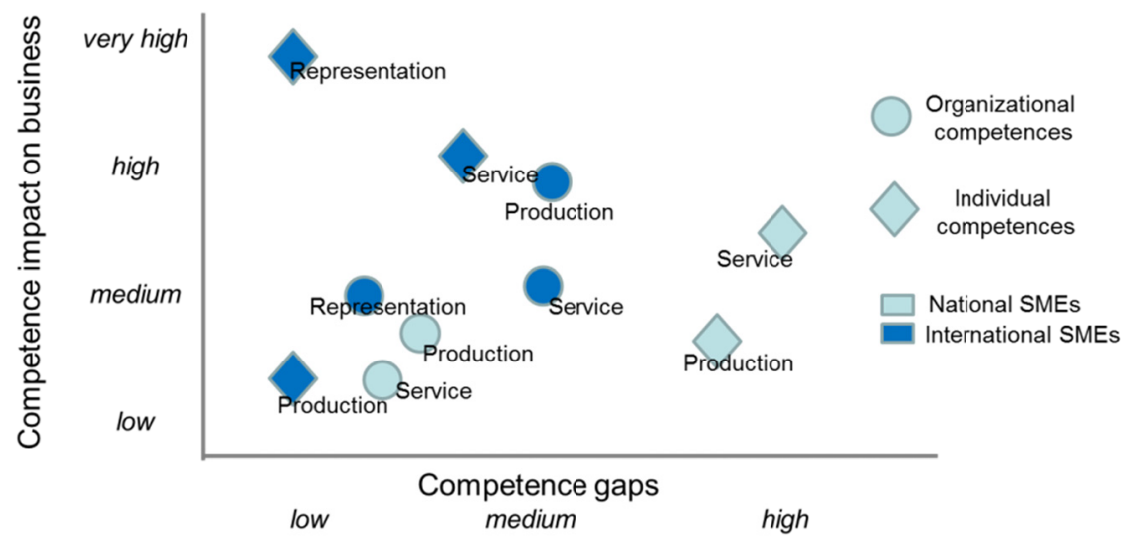

Figure 1. Illustration of competence gaps and competence impact on business

\section{Discussion}

After an examination of the most influential papers on internationalization competences of SMEs and the perceived competence gaps, we systematically determined what competences on individual and organization level are relevant for international SMEs and SMEs that intent to go international in the next two years. We have argued that the vast majority of internationalization literature does not take internationalization competence gaps that hinder the internationalization into account or explicitly states which competences are needed in which stage of the internationalization (Achtenhagen, 2011).

Instead, much of the literature focuses on internationalization models and approaches plainly. If competences appear on the stage, they refer to personal or socio-communicative competences of SMEs. As competences are broader defined in the competence literature (see Heyse \& Erpenbeck, 2004; Wilkens, 2004), we are curious in finding out "What kinds of competences gaps hinder SMEs to go international and what competence gaps arise when internationalizing?" Therefore, we place competences at the center of the attention of the internationalization process of SMEs (Laghzaoui, 2009). To answer our research question - two sets of SMEs were interviewed (in total 24 SMEs in Austria and China) ones that went international and ones that are currently only national with the intent to go abroad. In other words, we interviewed SMEs that were before and after their internationalization decision. Our sample consisted of SMEs in eight different sectors carrying out representation, production and service tasks in the international / national markets. Having 
analysed 11 SMEs before their internationalization decision and 13 SMEs after their internationalization, we found striking differences in the competence gaps and the ranked importance of competence gaps for business in the international markets.

Our results indicate that while internationalized SMEs perceive organizational competence gaps as higher as individual ones - exactly the opposite appears to be true for SMEs working exclusively in their home market. The latter case, individual competence gaps hinder more severe in the perception of the SME manager the decision to going international. Organizational competence gaps appear to be a challenge for internationalized SMEs rather than for national ones.

Turning the focus on the tasks and activities that different departments in an SME have to carry out, we found that all activities from purchasing, contract negotiations exporting, development, testing, production, processing technology, distribution, sales and marketing, quality, overseas management, and human resources are required but often lacking (Porter, 1998; Achtenhagen, 2011). In particular, our results show explicitly high competence gaps in operations, marketing and sales, as well as procurement and technology development at internationalized SMEs. SMEs that have their internationalization start ahead of them, lack international experience, international orientation and cross cultural communication as well as market skills.

In terms of competence gap closure proceedings, different approaches became evident. While one fraction will use networking and cooperation activities with suppliers and universities to enhance their capability to act others set clear emphasis on internal measures, like training, desk research, ramp-up marketing and technology skills. Where our study discovered medium to high gaps and in addition, medium to very high impact of competences on the business, we propose to define distinctive competence development measures and set them on high priority. In detail, cross cultural competence gaps were rated as medium severe in national and international SMEs (representation) - but however the impact of competences on business was rated high. We propose to systematically develop these competences via measures like ramp-up of culture specific knowledge and about references, structures as well as build-up first interpersonal relationships. Independent of the competence ramp-up measure, all competences have to be handled with care, as they can be lost when not protected or practiced over a period of time.

Referring to the literature, our results go in line with Lin (2010), who comments that "in case of lacking competences, SMEs will take incremental and progressive steps in internationalization" (Lin 2010, p. 14). We, foremost, argue that in order to start to go abroad, the emphasis should be on fostering the personal and socio-communicative competences. In the later stages of the internationalization process as the organization develops, organizational gaps become more obvious and therefore, the systematic development of the task relevant organization competences as well as the action and activity competences and method competence should move into the center of attention. As consequence, we propose a continuous, task-based approach to SME internationalization, because, when following the continuous but step-wise approach, entrepreneurs gain a clear cut understanding on when to focus on what kinds of competences to ramp-up. The SME management team is then equipped to build-up a forward looking competence ramp-up strategy and choose the suitable competence partners for the current phase of the internationalization process.

Even though, we count on the power of diversity in terms of competences that evolve over time and will arise depending on the activities carried out, in essence, what it boils down to in our understanding is the concrete translation of knowledge into international practice to impact the business in a positive sense.

\section{Conclusion, Limitations and Future Outlook}

Little attention has been paid to the extent to which individual and organizational competences gaps affect internationalization of SMEs. Therefore, exploring internationalization competences gaps of international and national SMEs have been at the center of attention in this study. With this paper, we connected dots in literature and illustrated that competences have to be dealt with from various perspectives. Based on the research results, scholars and practitioners have now an additional option to reflect the complexity of competences in and across international settings.

In principal, we can conclude that this paper tackles the internationalization research field by showing how important personal competences are in the pre-internationalization phase and how important organizational competences are during the internationalization. For SMEs carrying out production, individual competences have a low impact on the business, while SMEs engaged in services and representation state the opposite. The impact of organizational competences on the business varies largely: having a great impact in production, medium impact in services, and low impact in representation tasks of SMEs. The implications from these results are obvious: Competence development will vary heavily depending on the tasks and action-orientation of the SME. This has to be taken into account when setting up international operations. 
However, our study is not free from limitations. We see several ones that give rise to avenues for further research on advancing the understanding: First, this research is certainly only the first step in exploring internationalization competence. Our data did only include 24 Austrian SMEs. Therefore, our results are only reflecting a small proportion of the Austrian market. Therefore, a more comprehensive approach needs to clarify what lacking competences block the internationalization. Second, further research is needed to verify whether similar patters hold true in other countries. Even though, our sample consists of eight sectors, we would like to increase the number of SMEs per sector. Third, a large quantitative study may provide further insights into competence gaps and development over time at companies. Fourth, scholars should concentrate on the question on how to measure and evaluate competences more accurately. We used a four-point scale as this was already used in some of the firms. We propose to work with more than 4-point-scales in the future as this leaves more room to grasp the variations and development potential.

In essence, more critical research is necessary to understand and draw conclusions on the competence gaps hindering internationalization. We believe these insights will be especially valuable to SME managers who have to prepare themselves for the way of going international in the next years.

\section{References}

Achtenhagen, L. (2011). Internationalization of SME. Stockholm: Entreprenörskapsforum. AID-SMJ882>3.0.CO; 2-Z.

Anzengruber, J., \& Bernard, E. (2009). Designing a global competency management framework. Proceedings of the 2nd ISPIM Innovation Symposium, December, New York.

Barney, J. B. (1986). Strategic factor makers: Expectation, luck, and business strategy. Management Science, 32, 1231-1241. http://dx.doi.org/10.1287/mnsc.32.10.1231

Bigler, J., \& Nyffeler, N. (2006). Processus d'internationalisation de la PME: la nécessité d'uneapproche integrative. Communication à la 8ème CIFEPME, Octobre, Fribourg.

Boyatzis, R. E. (1982). The Competent Manager: A Model for Effective Performance. New York: John Wiley.

Chandra, Y., Styles, C. \& Wilkinson. I. (2009). The recognition of first time international entrepreneurial opportunities: evidence from firms in knowledge-based industries. International Marketing Review, 26(1), 30-61. http://dx.doi.org/10.1108/02651330910933195

DeFillippi, R., \& Arthur, M. (1996), Boundaryless Contexts and Careers: A Competency-Based Perspective. In M.B. Arthur and D.M. Rousseau (eds.) The Boundaryless Career. A New Employment Principle for a New Organizational Era. New York: Oxford University Press, 116-131.

Dhanaraj, C. A., \& Beamish, P. (2003). Resource-based approach to the study of export Performance. Journal of Small Business Management, 41, 242-261. http://dx.doi.org/10.1111/1540-627X.00080

Fleury, M., \& Fleury, A. (2005). In search of competence: aligning strategy and competences in the telecommunications industry. International Journal of Human Resource Management, 16, 1640-1655. http://dx.doi.org/10.1080/09585190500239275

Forsman, M., Hinttu, S., \& Kock, S. (2002). Internationalization from a SME Perspective. Paper presented at the IMP Conference, Dijon.

Fourcade, C. (2002). Le territoire comme atout des processus d'internationalisation des PME: Le concept de milieu internationalisant. Paper presented at Actes du XXVIIIÌme Colloque de l'ASRDLF, Trois-Rivières, Québec.

Freiling, J. (2004). A Competence-based Theory of the Firm. Management revue. The International Review of Management Studies, 15(1), 27-52.

Giada, D. S., Alfonso, G., \& Gianmario, V. (2012). Technology push and demand pull perspectives in innovation studies: Current findings and future research directions. Research Policy, 41, 1283-1295. http://dx.doi.org/10.1016/j.respol.2012.03.021

Grote, S., Kauffeld S., \& Frieling, E. (2006). Kompetenzmanagement. Grundlagen und Praxisbeispiele. Stuttgart: Schäffer-Poeschel.

Hamel, G., \& Prahalad, C. K. (1990). The core competence of the corporation. Harvard Business Review, 68, 79-91.

Hartley, J. (1994). Case studies in organizational research. In Catherine Cassell and Gillian Symon (eds.) Qualitative methods in organizational research, a practical guide. London: Sage, pp.208-229.

Hébert, L. (2002). Stratégies internationales et développement d'un leadership mondial. Gestion, 27, 78-85. http://dx.doi.org/10.3917/riges.271.0078

Heilmann, P. (2011). The dialectics between boundaryless career and competence development findings among Finnish 
ICT and paper manager. International Journal of Human Resource Management, 22, 181-196. http://dx.doi.org/10.1080/09585192.2011.538981

Heyse, V. \& Erpenbeck, J. (2004). Kompetenztraining-64 Informations- und Trainingsprogramme. Stuttgart: Schäffer-Poeschel.

Hutchinson, K., Quinn, B., \& Alexander, N. (2006). The role of management characteristics in the internationalization of SMEs, Evidence of from the UK retail. Journal of Small Business and Enterprise Development, 13, 513-534. http://dx.doi.org/10.1108/14626000610705723

Jacobides, M. G., \& Winter, S. G. (2012). Capabilities: Structure, agency, and evolution. Organization Science, Articles in Advance: 1-17. http://dx.doi.org/10.1287/orsc.1110.0716

Johanson, J., \& Vahlne, J. (1990). The Mechanisms of Internationalization. International Marketing Review, 7 (4), 11-24. http://dx.doi.org/10.1108/02651339010137414

Katwalo, A., \& Mulengani. (2006). An overview of competence development in SMEs. International Journal of Strategic Change Management, 1, 89-95. http://dx.doi.org/10.1504/IJSCM.2006.011104

Knight, G., \& Kim, D. (2009). International business competence and the contemporary firm. Journal of International Business Studies, 40, 255-273. http://dx.doi.org/10.1057/palgrave.jibs.8400397

Laghzaoui, S. (2009). Internationalisation des PME : apports d'une analyse en termes de ressources et competences. Revue Management \& Avenir, 2, 52-69. http://dx.doi.org/10.3917/mav.022.0052

Leonidou, L., \& Katsikeas, C. (1996). The export development process: An integrative review of empirical models. Journal of International Business Studies, 27, 517-551. http://dx.doi.org/10.1057/palgrave.jibs.8490846

Lin, S. (2010). Internationalization of SMEs: Towards an integrative approach of resources and competences; 1er Colloque Franco-Tchèque. Trends in International Business, http://halshs.archives-ouvertes.fr/halshs-00692465. 28.12.2012

McDougall, P., \& Oviatt, B. (2000). International Entrepreneurship: The intersection of Two Research Paths. Academy of Management Journal, 43, 902-908. http://dx.doi.org/10.2307/1556418

Nelson, R. and Winter, S. (1982). An evolutionary Theory of economic change. Cambridge, MA: Harvard University Press.

Pantin, F. (2005). La conduite de processus d'internationalisation par l'équipe dirigeante entre compétences stratégiques et compétences opérationnelles. XIVième Conférence Internationale de Management Stratégique, Angers, France.

Patton, E., \& Appelbaum, S. (2003). The case for case studies in management research. Management Research News, 26, 60-71. http://dx.doi.org/10.1108/01409170310783484

Penrose, E. T. (1959). The Theory of the Growth of the Firm. New York: John Wiley.

Porter, M. E. (1998). Clusters and the New Economics of Competition. Harvard Business Review, November December 1998: 77-90.

Rahmandad, H. (2012). Impact of Growth Opportunities and Competition on Firm-Level Capability Development Trade-offs. Organization Science, 23(1), 138-154. http://dx.doi.org/10.1287/orsc.1100.0628

Rasheed. H. (2005). Foreign Entry Mode and Performance: The Moderating Effects of Environment. Journal of Small Business Management, 43(1), 41-55. http://dx.doi.org/10.1111/j.1540-627X.2004.00124.x

Reuber, A. R., \& Fischer, E. (1997). The Influence of the Management Team's International Experience on the International Behaviors of SMEs. Journal of International Business Studies, 28, 807-825. http://dx.doi.org/10.1057/palgrave.jibs.8490120

Ruzzier, M., Hisrich, D., \& Bostjan, A. (2006). SME internationalisation research: past, present, and future. Journal of Small Business and Enterprise Development, 13, 476-497. http://dx.doi.org/10.1108/14626000610705705

Sanchez, R., \& Heene, A. (2004). The New Strategic Management: Organizations, Competition and Competence. Sussex: John Wiley \& Sons.

Suarez-Ortega, S., \& Alamo-Vera, F. (2005). SMEs' Internationalization: firms and managerial factors. International Journal of Entrepreneurial Behavior \& Research, 11, 258-279. http://dx.doi.org/10.1108/13552550510603298

Teece, D. J., Pisano, G., \& Shuen, A. (1997). Dynamic capabilities and strategic management. Strategic Management Journal, 18, 509 - 533. http://dx.doi.org/10.1002/(SICI)1097-0266(199708)18:7<509 
Wernerfelt, B. (1984). A Resource-based View of the Firm. Strategic Management Journal, 5, 171-180. http://dx.doi.org/10.1002/smj.4250050207.

Wilkens, U. (2004). Von der individuellen zur kollektiven Kompetenz?, Paper presented at Kommissionstagung Personal der Hochschullehrer für Betriebswirtschaft, September, Konstanz.

Wolff, J. A., \& Pett, T. L. (2000). Internationalization of small firms: An examination of export-strategy approach, firm size, and export performance. Journal of Small Business Management, 38, 34-47.

Yin, R. (1989). Case study research: Design and methods, Rev. ed. Beverly Hills, CA: Sage Publishing.

Yin, R. (1994). Case study research: Design and methods, 2nd ed. Beverly Hills, CA: Sage Publishing.

\section{(cc) EY}

This work is licensed under a Creative Commons Attribution 3.0 License. 